\title{
Interim effectiveness of trivalent influenza vaccine in a season dominated by lineage mismatched influenza $B$, northern Spain, 2017/18
}

Jesús Castilla ${ }^{1,2}$, Ana Navascués ${ }^{3}$, Itziar Casado ${ }^{1,2}$, Alejandra Pérez-García ${ }^{2,3}$, Aitziber Aguinaga ${ }^{3}$, Guillermo Ezpeleta ${ }^{1}$, Francisco Pozo $^{4}$, Carmen Ezpeleta ${ }^{3}$, Iván Martínez-Baz ${ }^{1,2}$, Primary Health Care Sentinel Network ${ }^{5}$, Network for Influenza Surveillance in Hospitals of Navarre ${ }^{5}$

1. Instituto de Salud Pública de Navarra, IdiSNA - Navarre Institute for Health Research, Pamplona, Spain

2. CIBER Epidemiología y Salud Pública (CIBERESP), Spain

3. Servicio de Microbiología, Complejo Hospitalario de Navarra, IdiSNA - Navarre Institute for Health Research, Pamplona, Spain

4. Centro Nacional de Microbiología (WHO National Influenza Centre - Madrid), Instituto de Salud Carlos III, Majadahonda, Spain

5. The members of these networks are listed at the end of the article.

Correspondence: Jesús Castilla (jcastilc@navarra.es)

Castilla Jesús, Navascués Ana, Casado Itziar, Pérez-García Alejandra, Aguinaga Aitziber, Ezpeleta Guillermo, Pozo Francisco, Ezpeleta Carmen, Martínez-Baz Iván, Primary Health Care Sentinel Network, Network for Influenza Surveillance in Hospitals of Navarre. Interim effectiveness of trivalent influenza vaccine in a season dominated by lineage mismatched influenza B, northern Spain, 2017/18. Euro Surveill. 2018;23(7): pii=18-00057. https://doi.org/10.2807/1560-7917. ES.2018.23.7.18-00057

The 2017/18 interim estimate of trivalent influenza vaccine effectiveness (VE) was 39\% (95\% confidence interval: $20-54$ ) in Navarre. Compared with individuals unvaccinated in the current and five previous seasons, VE against influenza B was $41 \%$ for current and any prior doses, $67 \%$ for current vaccination only, and $22 \%$ for any prior doses, and $43 \%, 51 \%$ and $54 \%$, respectively against influenza $\mathrm{A}\left(\mathrm{H}_{3} \mathrm{~N}_{2}\right)$. This suggests moderate VE despite predominance of lineage mismatched influenza $B$.

The early 2017/18 influenza season in Europe was characterised by co-circulation of influenza $B, A\left(\mathrm{H}_{3} \mathrm{~N}_{2}\right)$ and $A\left(\mathrm{H}_{1} \mathrm{~N}_{1}\right) p d m o 9$, with lineage mismatched influenza $\mathrm{B}$ (Yamagata) virus predominating in many countries $[1,2]$. Concerns arose due to the low influenza vaccine effectiveness (VE) reported in the 2017 influenza $\mathrm{A}\left(\mathrm{H}_{3} \mathrm{~N}_{2}\right)$ epidemic in Australia [3] and the warning about low VE of the trivalent influenza vaccine (TIV) against a lineage mismatched influenza $B$ (Yamagata) virus [4]. Influenza vaccination in previous seasons may retain some preventive effect and modify the effect of the current season vaccination so the vaccination history should be considered in the VE assessment $[5,6]$.

We present the $2017 / 18$ interim effectiveness estimates of different combinations of current and prior season influenza vaccination in preventing laboratoryconfirmed influenza.

\section{Study design and information sources}

A test-negative case-control study was used for the estimations. Cases and controls were identified through the influenza epidemiological and virological surveillance in primary healthcare and hospitals in Navarre, northern Spain. In October and November 2017, the trivalent inactivated non-adjuvanted vaccine was offered free of charge to the target population for vaccination, which included people aged 60 years or more and people with major chronic conditions. The TIV comprised influenza A/Michigan/45/2015(H1N1)like, A/HongKong/4801/2014( $\left.\mathrm{H}_{3} \mathrm{~N}_{2}\right)$-like and $\mathrm{B} /$ Brisbane/60/2008(Victoria-lineage)-like antigens [7]. The TIV had contained $\mathrm{B}$ (Yamagata) antigens in the $2012 / 13$ to $2015 / 16$ seasons [8]. Influenza vaccine status in the current and five prior influenza seasons, $2012 / 13$ to $2017 / 18$, was obtained from the regional vaccination register, where all vaccines administered in healthcare centres are registered online [9]. Persons were considered to be protected by the vaccine 14 days after receiving it.

Influenza surveillance relied on all primary healthcare physicians and hospitals automatically reporting influenza-like illness (ILI) cases [6]. A sentinel network of primary healthcare physicians collected nasopharyngeal and pharyngeal swabs from their patients diagnosed with ILI, when symptoms had appeared less than five days before. In hospitals, early detection and swabbing of all hospitalised patients with ILI was specified by the protocol. Samples were processed by reverse-transcription PCR assay. A selection of representative strains of each week and virus type/subtype was sent to the National Influenza Centre-Madrid laboratory to be completely genetically characterised.

\section{Statistical analysis}

The study population included individuals covered by the Navarre Health Service since 2012 (96\% of the population). All ILI patients who were swabbed in 
TABLE 1

Characteristics of the patients with medically-attended influenza-like illness included in the test-negative case-control analysis, Navarre, Spain, December 2017-January 2018 ( $\mathrm{n}=1,268$ patients)

\begin{tabular}{|c|c|c|c|c|c|c|c|c|c|c|}
\hline \multirow{2}{*}{ Characteristics } & \multicolumn{2}{|c|}{ Test-negative controls } & \multicolumn{2}{|c|}{ All influenza cases } & \multicolumn{2}{|c|}{ Influenza B } & \multicolumn{2}{|c|}{ Influenza $\mathrm{A}\left(\mathrm{H}_{3} \mathrm{~N}_{2}\right)$} & \multicolumn{2}{|c|}{ Influenza $\mathrm{A}\left(\mathrm{H}_{1} \mathrm{~N}_{1}\right)$ pdmog } \\
\hline & $\mathrm{N}$ & $\%$ & $\mathrm{~N}$ & $\%$ & $N$ & $\%$ & $\mathrm{~N}$ & $\%$ & $\mathrm{~N}$ & $\%$ \\
\hline \multicolumn{11}{|l|}{ Age groups (years) } \\
\hline $9-24$ & 14 & 2 & 35 & 5 & 30 & 6 & 2 & 2 & 3 & 8 \\
\hline $25-44$ & 89 & 15 & 150 & 23 & 109 & 22 & 27 & 22 & 14 & 39 \\
\hline $45-64$ & 123 & 20 & 170 & 26 & 136 & 27 & 25 & 21 & 8 & 22 \\
\hline $65-84$ & 271 & 44 & 203 & 31 & 158 & 32 & 37 & 32 & 8 & 22 \\
\hline$\geq 85$ & 117 & 19 & 96 & 15 & 65 & 13 & 27 & 23 & 3 & 8 \\
\hline \multicolumn{11}{|l|}{ Sex } \\
\hline Male & 336 & 55 & 311 & 48 & 230 & 46 & 62 & 52 & 18 & 50 \\
\hline Female & 278 & 45 & 343 & 52 & 268 & 54 & 56 & 48 & 18 & 50 \\
\hline \multicolumn{11}{|c|}{ Major chronic conditions } \\
\hline No & 167 & 27 & 278 & 43 & 221 & 44 & 37 & 31 & 19 & 53 \\
\hline Yes & 447 & 73 & 376 & 57 & 277 & 56 & 80 & 69 & 17 & 47 \\
\hline \multicolumn{11}{|l|}{ Month of swabbing } \\
\hline December & 178 & 29 & 91 & 14 & 76 & 15 & 11 & 9 & 4 & 11 \\
\hline January & 436 & 71 & 563 & 86 & 422 & 85 & 107 & 91 & 32 & 89 \\
\hline \multicolumn{11}{|c|}{ Target group for vaccination $^{a}$} \\
\hline No & 110 & 18 & 210 & 32 & 164 & 33 & 27 & 23 & 18 & 50 \\
\hline Yes & 504 & 82 & 444 & 68 & 334 & 67 & 91 & 77 & 18 & 50 \\
\hline \multicolumn{11}{|l|}{ Healthcare setting } \\
\hline Primary healthcare & 131 & 21 & 329 & 50 & 264 & 53 & 43 & 37 & 22 & 61 \\
\hline Hospitalization & 483 & 79 & 325 & 50 & 234 & 47 & 75 & 63 & 14 & 39 \\
\hline \multicolumn{11}{|c|}{$2017 / 18$ season vaccine } \\
\hline No & 283 & 46 & 423 & 65 & 328 & 66 & 66 & 56 & 28 & 78 \\
\hline Yes & 331 & 54 & 231 & 35 & 170 & 34 & 52 & 44 & 8 & 22 \\
\hline Total & 614 & 100 & 654 & $100^{b}$ & 498 & 100 & 118 & 100 & 36 & 100 \\
\hline
\end{tabular}

${ }^{a}$ Target group for vaccination includes people $\geq 60$ years-old and people with major chronic conditions.

${ }^{b}$ Two cases were influenza A not subtyped.

December 2017 and January 2018 were considered. We excluded healthcare workers, people living in nursing homes, children under 9 years of age and patients hospitalised prior to ILI symptom onset. The seasonal vaccination status of patients testing positive for influenza virus (cases) was compared to that of those who were negative for this virus (controls). Logistic regression models were employed to derive crude and adjusted odds ratios (OR) with their $95 \%$ confidence intervals (CI). Adjusted models included sex, age group (9-24, 25-44, 45-64, 65-84 and $\geq 85$ years), major chronic conditions, month of swabbing and healthcare setting. Four categories combining the current-season and five prior season vaccination were considered: current-season vaccination and any prior doses, current-season vaccination and no prior doses, no current-season vaccination and any prior doses, and no current-season vaccination and no prior doses (reference group). VE was estimated as a percentage: $(1-$ OR) $\times 100$.

\section{Influenza vaccine effectiveness interim estimation}

A total of 1,268 ILI patients were included, 808 (64\%) inpatients and 460 (36\%) primary healthcare patients. A total of 654 (52\%) were confirmed cases for influenza virus: 498 (76\%) for influenza $B, 118$ (18\%) for $A\left(\mathrm{H}_{3} \mathrm{~N}_{2}\right)$, $36(6 \%)$ for $A\left(\mathrm{H}_{1} \mathrm{~N}_{1}\right)$ pdmog and two non-subtyped influenza $A$ viruses.

The sequence derived from the amplification product of the $\mathrm{HA}_{1}$ fragment of the haemagglutinin gene was characterised for 51 viruses. Of 40 influenza B viruses, 35 were $B /$ Phuket/3073/2013(Yamagata-lineage)-like, three $B /$ Brisbane/60/2008(Victoria-lineage)-like and two B/Norway/2409/2017(Victoria-lineage)-like. The four $A\left(\mathrm{H}_{1} \mathrm{~N}_{1}\right)$ pdmog strains were $A /$ Michigan/45/2015like. Among seven $\mathrm{A}\left(\mathrm{H}_{3} \mathrm{~N}_{2}\right)$ strains, five were A/HongKong/4801/2014-like and two A/ Singapore/16-0019/2016-like.

Compared with test-negative controls, influenza cases comprised a lower proportion of individuals aged 
Influenza vaccine effectiveness in preventing laboratory-confirmed influenza among individuals aged 9 years or older in Navarre, Spain, December 2017-January $2018(\mathrm{n}=1,268$ patients)

\begin{tabular}{|c|c|c|c|c|}
\hline Models & $\begin{array}{c}\text { Controls } \\
\text { Vaccinated/unvaccinated }\end{array}$ & $\begin{array}{c}\text { Cases } \\
\text { Vaccinated/unvaccinated }\end{array}$ & $\begin{array}{l}\begin{array}{l}\text { Crude vaccine } \\
\text { effectiveness }\end{array} \\
\%(95 \% \mathrm{Cl})\end{array}$ & $\begin{array}{c}\begin{array}{c}\text { Adjusted vaccine } \\
\text { effectiveness }\end{array} \\
\%(95 \% \mathrm{Cl})^{\mathrm{a}} \\
\end{array}$ \\
\hline All swabbed patients & $331 / 283$ & $231 / 423$ & $53(42$ to 63$)$ & $39(20$ to 54$)$ \\
\hline Target group for vaccination ${ }^{b}$ & $318 / 186$ & $216 / 228$ & $45(28$ to 57$)$ & $39(17$ to 54$)$ \\
\hline \multicolumn{5}{|l|}{ Age group } \\
\hline $9-64$ years & $54 / 172$ & $41 / 314$ & $58(35$ to 73$)$ & 55 (26 to 73$)$ \\
\hline$\geq 65$ years & $277 / 111$ & $190 / 109$ & $30(4$ to 49$)$ & $30(2$ to 50$)$ \\
\hline \multicolumn{5}{|l|}{ Virus type/subtype } \\
\hline Influenza B & $331 / 283$ & $170 / 328$ & $56(43$ to 65$)$ & $41(20$ to 56$)$ \\
\hline Influenza $\mathrm{A}\left(\mathrm{H}_{3} \mathrm{~N}_{2}\right)$ & $331 / 283$ & $52 / 66$ & 33 (o to 55 ) & $29(-15$ to 57$)$ \\
\hline Influenza A(H1N1)pdmo9 & $331 / 283$ & $8 / 28$ & 76 (46 to 89$)$ & $59(-6$ to 84$)$ \\
\hline \multicolumn{5}{|l|}{ Primary healthcare patients } \\
\hline All influenza viruses & $35 / 96$ & $56 / 273$ & $44(9$ to 65$)$ & $51(13$ to 73$)$ \\
\hline Influenza B & $35 / 96$ & $47 / 217$ & $41(2$ to 64$)$ & $52(12$ to 74$)$ \\
\hline Influenza $\mathrm{A}\left(\mathrm{H}_{3} \mathrm{~N}_{2}\right)$ & $35 / 96$ & $6 / 37$ & $56(-14$ to 83$)$ & $54(-44$ to 85$)$ \\
\hline Influenza A(H1N1)pdmog & $35 / 96$ & $3 / 19$ & $57(-55$ to 88$)$ & $49(-120$ to 88$)$ \\
\hline \multicolumn{5}{|l|}{ Hospitalised patients } \\
\hline All influenza viruses & $296 / 187$ & $175 / 150$ & $26(2$ to 45$)$ & 35 (11 to 53$)$ \\
\hline Influenza B & $296 / 187$ & $123 / 111$ & $30(4$ to 49$)$ & $37(11$ to 55$)$ \\
\hline Influenza $\mathrm{A}\left(\mathrm{H}_{3} \mathrm{~N}_{2}\right)$ & $296 / 187$ & $46 / 29$ & o $(-65$ to 39$)$ & $20(-40$ to 54$)$ \\
\hline Influenza A(H1N1)pdmog & $296 / 187$ & $5 / 9$ & $65(-6$ to 88$)$ & $63(-27$ to 89$)$ \\
\hline
\end{tabular}

$\mathrm{Cl}$ : confidence interval.

${ }^{a}$ Logistic regression model adjusted for sex, age group $(9-24,25-44,45-64,65-85$ and $\geq 85$ years), major chronic conditions, month of swabbing and healthcare setting (primary healthcare and hospital).

b Target group for vaccination includes people $\geq 60$ years old and people with major chronic conditions.

65 years or older, of persons with comorbidities or who were attended in hospitals. Among cases, 35\% $(231 / 654)$ had been vaccinated in the $2017 / 18$ season vs $54 \%(331 / 614)$ among controls ( $p<0.001)$ (Table 1$)$.

Regardless of the vaccination history, the overall adjusted estimate of influenza VE was $39 \%$ ( $95 \% \mathrm{Cl}: 20$ to 54 ). In persons less than 65 years-old the estimates were higher (55\%) than in the older age group (30\%), and in outpatients (51\%) than inpatients (35\%). VE was $41 \%$ (95\% Cl: 20 to 56 ) against influenza $\mathrm{B}, 29 \%(95 \% \mathrm{Cl}:-15$ to 57$)$ against $\mathrm{A}\left(\mathrm{H}_{3} \mathrm{~N}_{2}\right)$, and $59 \%$ (95\% Cl: -6 to 84 ) against $\mathrm{A}\left(\mathrm{H}_{1} \mathrm{~N}_{1}\right)$ pdmog (Table 2).

Nevertheless, better levels of protection were observed in the analysis considering the vaccination history. Compared with persons never vaccinated in the current and five previous seasons, the preventive effect was $42 \%$ (95\% Cl: 20 to 58 ) in those vaccinated in the current and any prior seasons, $65 \%$ (95\% Cl: 32 to 82 ) in those vaccinated only in the current season, and $28 \%$ ( $95 \% \mathrm{Cl}:-11$ to 53 ) in those vaccinated only in any prior seasons. The corresponding estimates against influenza $\mathrm{B}$ were $41 \%$ (95\% Cl: 17 to 59$), 67 \%$ (95\% Cl: 31 to 84 ) and $22 \%(95 \% \mathrm{Cl}:-24$ to 51$)$, and against $\mathrm{A}\left(\mathrm{H}_{3} \mathrm{~N}_{2}\right)$ were $43 \%(95 \% \mathrm{Cl}:-1$ to 67$), 51 \%(95 \% \mathrm{Cl}:-51$ to 84$)$ and $54 \%$ (95\% Cl: -7 to 80 ), respectively (Table 3).

\section{Discussion}

These results suggest a protective effect of the TIV of $42 \%$ to $65 \%$ in the early $2017 / 18$ season in Navarre, depending on the vaccination status in prior seasons. Moderate VE was observed against influenza $B$, $\mathrm{A}\left(\mathrm{H}_{1} \mathrm{~N}_{1}\right)$ pdmog and $\mathrm{A}\left(\mathrm{H}_{3} \mathrm{~N}_{2}\right)$.

Our results on influenza $B$ are consistent with those recently reported from Canada [10] and contrast with the low VE expected in a season dominated by lineage mismatched influenza $B$ virus [4]. Although we observed some preventive effect of previous vaccinations in individuals unvaccinated in the current season, the highest VE against influenza B was seen in people vaccinated in the current season but not vaccinated in prior ones, ruling out the possibility that the observed VE is due to the residual effect of previous vaccines containing $\mathrm{B}$ (Yamagata). Instead, this notable effectiveness of the TIV against influenza B suggests important cross-lineage protection [10-15]. 
TABLE 3

Effectiveness of current season influenza vaccination and of vaccination in the five prior seasons in preventing laboratoryconfirmed influenza cases among people aged 9 years or older, Navarre, Spain, December 2017-January 2018 ( $\mathrm{n}=1,268$ patients)

\begin{tabular}{|c|c|c|c|}
\hline Vaccination history by type of patients or influenza & Cases/controls & $\begin{array}{l}\text { Crude vaccine effectiveness } \\
\qquad \%(95 \% \mathrm{Cl})\end{array}$ & $\begin{array}{c}\text { Adjusted vaccine effectiveness } \\
\qquad \%(95 \% \mathrm{Cl})^{\mathrm{a}}\end{array}$ \\
\hline \multicolumn{4}{|l|}{ All patients } \\
\hline Never vaccinated & $366 / 211$ & Reference & Reference \\
\hline No current + any prior dose & $57 / 72$ & $54(33$ to 69$)$ & $28(-11$ to 53$)$ \\
\hline Current only & $17 / 28$ & $65(35$ to 81$)$ & 65 (32 to 82$)$ \\
\hline Current + any prior dose & $214 / 303$ & 59 (48 to 68$)$ & $42(20$ to 58$)$ \\
\hline \multicolumn{4}{|l|}{ Primary healthcare patients } \\
\hline Never vaccinated & $261 / 87$ & Reference & Reference \\
\hline No current + any prior dose & $12 / 9$ & $56(-9$ to 82$)$ & $51(-25$ to 81$)$ \\
\hline Current only & $8 / 11$ & 76 (38 to 91$)$ & 79 (42 to 92) \\
\hline Current + any prior dose & $48 / 24$ & $33(-15$ to 61$)$ & $39(-20$ to 69$)$ \\
\hline \multicolumn{4}{|l|}{ Hospitalised patients } \\
\hline Never vaccinated & $105 / 124$ & Reference & Reference \\
\hline No current + any prior dose & $45 / 63$ & $16(-34$ to 47$)$ & $20(-31$ to 52$)$ \\
\hline Current only & $9 / 17$ & $38(-46$ to 73$)$ & $47(-28$ to 78$)$ \\
\hline Current + any prior dose & $166 / 279$ & $30(3$ to 49$)$ & 41 (13 to 59$)$ \\
\hline \multicolumn{4}{|l|}{ Influenza B } \\
\hline Never vaccinated & $283 / 211$ & Reference & Reference \\
\hline No current + any prior dose & $45 / 72$ & $53(30$ to 69$)$ & $22(-24$ to 51$)$ \\
\hline Current only & $13 / 28$ & $65(32$ to 83$)$ & $67(31$ to 84$)$ \\
\hline Current + any prior dose & $157 / 303$ & $61(50$ to 70$)$ & 41 (17 to 59$)$ \\
\hline \multicolumn{4}{|l|}{ Influenza $\mathrm{A}\left(\mathrm{H}_{3} \mathrm{~N}_{2}\right)$} \\
\hline Never vaccinated & $28 / 211$ & Reference & Reference \\
\hline No current + any prior dose & $8 / 72$ & 60 (11 to 82$)$ & $54(-7$ to 80$)$ \\
\hline Current only & $4 / 28$ & $48(-54$ to 83$)$ & $51(-51$ to 84$)$ \\
\hline Current + any prior dose & $48 / 303$ & 42 (11 to 82$)$ & $43(-1$ to 67$)$ \\
\hline
\end{tabular}

$\mathrm{Cl}$ : confidence interval.

a Vaccine effectiveness adjusted by age groups $(9-24,25-44,45-64,65-84$ and $\geq 85$ years), sex, major chronic conditions, healthcare setting (primary healthcare and hospital), and month of swabbing.

The moderate VE against influenza $\mathrm{A}\left(\mathrm{H}_{3} \mathrm{~N}_{2}\right)$ observed in the analysis adjusted for vaccination history contrasts with the lower estimate from the analysis that only considers current season vaccination, indicating that the vaccination history may be a confounding factor [6]. By including in the analyses any vaccination in the five prior seasons, the reference category was not affected by residual vaccine effect.

Our results from two independent groups, i.e. hospitalised patients and primary healthcare patients, were broadly consistent. The lower point estimates among inpatients in some analyses might be explained by the poorer immune response of patients who required hospitalisation.

This study has some limitations. The number of influenza $B$ cases with known lineage was too small to obtain estimates by lineage, although $88 \%$ of known lineages were Yamagata. The results are preliminary and for some analyses, the statistical power is limited. Nevertheless, selection bias was reduced by recruiting laboratory-confirmed cases and controls in the same settings before either patient or physician was aware of laboratory results [16]. We also included outpatients and inpatients, thus obtaining broad representation of patients with influenza. The analyses were adjusted for the healthcare setting as this variable could have acted as a confounding factor.

In conclusion, these results suggest moderate effectiveness of the trivalent inactivated influenza vaccine against the three circulating viruses in the early 2017/18 season in northern Spain. The TIV effectiveness against influenza $B$ suggests an important crosslineage protection. 
Members of the Primary Health Care Sentinel Network and of the Network for Influenza Surveillance in Hospitals of Navarre

The members of the Primary Health Care Sentinel Network of Navarre are:

I Abad, P Aldaz, R Ansorena, I Arcéiz, E Arina, MA Arrechea, I Arribas, N Aznárez, FC Bartolomé, A Beguiristain, A Beltrán, M Bidarte, I Blanco, A Brugos, B Cano, MV Castresana, JC Cenoz, F Cia, B Compains, JR Corpas, F Cortes, B Churío, PC Cuevas, EM Da Costa, MR Díez, FJ Escribano, M Esparza, MJ Esparza, V Etayo, C Fernández Alfaro, B Flamarique, ML Garcés, T García Albéniz, FJ García Nicolás, AB Germán, A Giner, JO Guiu, JC Gurbindo, MJ Guruchaga, JA Heras, M Hernández Galindo, MC Hijos, B Iñigo, MC Irigoyen, J Jurio, S Lizarraga, MJ Lizaso, JJ Longás, MJ López, MT Maquirriain, M Mazquiarán, JJ Miner, T Molins, M Moreno, MA Moros, U Navarro, E Orbara, M Orte, M Oscoz, P Palacio, J Palau, C Pérez Lecumberri, P Pérez Pascual, B Pérez Sanz, MJ Plumbed, A Prado Virto, M Prado Santamaría, A Puig Arrastia, M Ramos, BE Rípodas, M Rodríguez, MA Roncal, I Ruiz Puertas, C Sánchez, F Sánchez Miramón, P Sarrasqueta, F Satrústegui, MA Senosiáin, M Sota, ME Ursua, IA Urtasun, M Zardoya, ME Zubieta, F Elía, E Albéniz.

The members of the Network for Influenza Surveillance in Hospitals of Navarre are:

A Aguinaga, P Artajo, C Beaumont, X Beristain, J Chamorro, C Ezpeleta, F Gallinas, A Pérez-García, M Herranz, J Hueto, L Moreno, S Martínez-Pérez, A Navascués, N Viguria, J Sesma (Complejo Hospitalario de Navarra), I Estévez, JJ García Irure (Hospital Reina Sofía, Tudela), F Lameiro, Al Álvaro (Hospital García Orcoyen, Estella), I Casado, G Ezpeleta, M García Cenoz, J Castilla (Instituto de Salud Pública de Navarra).

\section{Acknowledgements}

This study was supported by the Horizon 2020 program of the European Commission (agreement 634446); by the I-MOVE (Influenza Monitoring Vaccine Effectiveness in Europe) Network funded by the European Centre for Disease Prevention and Control; and by the Carlos III Institute of Health with the European Regional Development Fund (CM15/00119, INT16/00122).

\section{Conflict of interest}

None declared.

\section{Authors' contributions}

J Castilla, A Navascués, I Casado and I Martínez-Baz designed the study and coordinated the activities. I Martínez-Baz, I Casado and J Castilla undertook the statistical analysis. A Navascués, A Aguinaga, A Pérez-García, C Ezpeleta and F Pozo were responsible of the virological analysis and the interpretation of laboratory results. G Ezpeleta, I Casado, the Primary Health Care Sentinel Network, and the Network for Influenza Surveillance in Hospitals of Navarre participated in the data collection. J Castilla, I Casado and I Martínez-Baz wrote the draft manuscript, and all authors revised and approved the final version.
Stockholm: ECDC. [Accessed 12 Feb 2018]. Available from: https://ecdc.europa.eu/en/publications-data/ weekly-influenza-update-week-5-january-2018

2. Sistema de Vigilancia de la Gripe en España. Informe semanal de Vigilancia de la Gripe en España. Semana 5/2018 № 531. [Weekly report of the influenza surveillance system in Spain 5/2018. No 531]. Madrid: Instituto de Salud Carlos III; 8 February 2018. Spanish. Available from: http://vgripe.isciii.es/ documentos/20172018/boletines/grno52018.pdf

3. Sullivan SG, Chilver MB, Carville KS, Deng YM, Grant KA, Higgins G, et al. Low interim influenza vaccine effectiveness, Australia, 1 May to 24 September 2017. Euro Surveill. 2017;22(43):17-00707. https://doi.org/10.2807/1560-7917. ES.2017.22.43.17-00707 PMID: 29090681

4. Wise J. Trivalent flu vaccine won't protect against influenza B strain predominantly circulating. BMJ. 2018;360:k78. https:// doi.org/10.1136/bmj.k78 PMID: 29305384

5. McLean HQ, Thompson MG, Sundaram ME, Meece JK, McClure $\mathrm{DL}$, Friedrich TC, et al. Impact of repeated vaccination on vaccine effectiveness against influenza $A\left(\mathrm{H}_{3} \mathrm{~N}_{2}\right)$ and $B$ during 8 seasons. Clin Infect Dis. 2014;59(10):1375-85. https://doi. org/10.1093/cid/ciu680 PMID: 25270645

6. Castilla J, Navascués A, Casado I, Díaz-González J, Pérez-García A, Fernandino L, et al. Primary Health Care Sentinel Network And The Network For Influenza Surveillance In Hospitals of Navarre. Combined effectiveness of prior and current season influenza vaccination in northern Spain: 2016/17 mid-season analysis. Euro Surveill. 2017;22(7):30465. https://doi. org/10.2807/1560-7917.ES.2017.22.7.30465 PMID: 28230523

7. Recommended composition of influenza virus vaccines for use in the 2017-2018 northern hemisphere influenza season. Wkly Epidemiol Rec. 2017;92(11):117-28. PMID: 28303704

8. Recommended composition of influenza virus vaccines for use in the 2016-2017 northern hemisphere influenza season. Wkly Epidemiol Rec. 2016;91(10):121-32. PMID: 26971356

9. Aguilar I, Reyes M, Martínez-Baz I, Guevara M, Albéniz E, Belza $M$, et al. Use of the vaccination register to evaluate influenza vaccine coverage in seniors in the 2010/11 influenza season, Navarre, Spain. Euro Surveill. 2012;17(17):20154. https://doi. org/10.2807/ese.17.17.20154-en PMID: 22551499

10. Skowronski DM, Chambers C, De Serres G, Dickinson JA, Winter AL, Hickman R, et al. Early season co-circulation of influenza $A\left(\mathrm{H}_{3} \mathrm{~N}_{2}\right)$ and $B($ Yamagata): interim estimates of 2017/18 vaccine effectiveness, Canada, January 2018. Euro Surveill. 2018;23(5):1800035. https://doi.org/10.2807/15607917.ES.2018.23.5.18-00035 PMID: 29409570

11. McLean HQ, Thompson MG, Sundaram ME, Kieke BA, Gaglani $M$, Murthy $K$, et al. Influenza vaccine effectiveness in the United States during 2012-2013: variable protection by age and virus type. J Infect Dis. 2015;211(10):1529-40. https://doi. org/10.1093/infdis/jiu647 PMID: 25406334

12. Skowronski DM, Janjua NZ, Sabaiduc S, De Serres G, Winter AL, Gubbay JB, et al. Influenza A/subtype and B/lineage effectiveness estimates for the 2011-2012 trivalent vaccine: cross-season and cross-lineage protection with unchanged vaccine. J Infect Dis. 2014;210(1):126-37. https://doi. org/10.1093/infdis/jiuo48 PMID: 24446529

13. Janjua NZ, Skowronski DM, De Serres G, Dickinson J, Crowcroft NS, Taylor M, et al. Estimates of influenza vaccine effectiveness for 2007-2008 from Canada's sentinel surveillance system: cross-protection against major and minor variants. J Infect Dis. 2012;205(12):1858-68. https://doi. org/10.1093/infdis/jis283 PMID: 22492921

14. Skowronski DM, Masaro C, Kwindt TL, Mak A, Petric M, Li Y, et al. Estimating vaccine effectiveness against laboratoryconfirmed influenza using a sentinel physician network: results from the 2005-2006 season of dual $A$ and $B$ vaccine mismatch in Canada. Vaccine. 2007;25(15):2842-51. https:// doi.org/10.1016/j.vaccine.2006.10.002 PMID: 17081662

15. Skowronski DM, Chambers C, Sabaiduc S, De Serres G, Winter AL, Dickinson JA, et al. Beyond antigenic match: possible agent-host and immuno-epidemiological influences on influenza vaccine effectiveness during the 2015-2016 season in Canada. J Infect Dis. 2017;216(12):1487-500. https://doi. org/10.1093/infdis/jix526 PMID: 29029166

16. Valenciano M, Kissling E, Ciancio BC, Moren A. Study designs for timely estimation of influenza vaccine effectiveness using European sentinel practitioner networks. Vaccine. 2010;28(46):7381-8. https://doi.org/10.1016/j. vaccine.2010.09.010 PMID: 20851086

\section{References}

1. European Centre for Disease Prevention and Control

(ECDC). Weekly influenza update, week 5, January 2018. 


\section{License and copyright}

This is an open-access article distributed under the terms of the Creative Commons Attribution (CC BY 4.0) Licence. You may share and adapt the material, but must give appropriate credit to the source, provide a link to the licence, and indicate if changes were made.

This article is copyright of the authors, 2018. 